ANADOLU, J. of AARI

ISSN: 1300-0225 (Print)

E-ISSN: 2667-6087 (Online)

2020, 30 (1): 33-45

DOI: $10.18615 /$ anadolu. 727197

\title{
Iris sari Schott ex Baker'nin In Vitro Çoğaltım ve Köklendirme Çalışmaları
}

\author{
Selay DO $\breve{G} A N^{1 *}$ (D) Gülat ÇA $\breve{G} L A R^{2}$ \\ ${ }^{1}$ Ege Tarımsal Araştırma Enstitüsü Müdürlüğ̈̈, Menemen-İzmir/TURKEY \\ ${ }^{2}$ Emekli öğretim üyesi. Sütçü İmam Üniv., Zir. Fak., Bahçe Bitkileri Bölümü, Kahramanmaraş/TURKEY \\ ${ }^{1}$ https://orcid.org/0000-0003-0589-3963 $\quad{ }^{2}$ https://orcid.org/0000-0001-8444-1230 \\ * Corresponding author (Sorumlu yazar): selay.eldogan@tarimorman.gov.tr \\ Received (Geliş tarihi): 11.07.2019 Accepted (Kabul tarihi): 30.01.2020
}

\begin{abstract}
ÖZ: Bitki biyoçeşitliliğinin korunmasına yönelik biyoteknolojik uygulamalardan biri olan doku kültürü teknikleri özellikle endemik bitkilerin korunmasında sıklıkla kullanılmaktadır. Iridaceae familyasının endemik bir türü olan Iris sari Schott ex Baker, ülkemizde doğal yayılıs alanlarına sahiptir. Çalışmamızın amacı, Türkiye'nin geofitleri arasında yer alan Iris sari Schott ex Baker'nin in vitro tekniklerle vejetatif çoğaltımı ve etkili köklendirme olanaklarının araştırılmasıdır. Bu amaçla, Iris sari Schott ex Baker'nin bitkisine ait olgunlaşmamış embriyolar başlangıç eksplantı olarak kullanılmıştır. In vitro çoğaltım çalışmaları sonucunda elde edilen sürgünler ile köklendirme çalışmaları yapılmıştır. Çalışmalar sonucunda, en iyi çoğaltım oranı eksplant başına 10,3 adet sürgün ile 0,5 $\mathrm{mg} \mathrm{l}^{-1} \mathrm{NAA}+1,0 \mathrm{mg} \mathrm{l}^{-1}$ BAP içeren MS ortamında gözlenmiştir. Çoğaltılan sürgünlerin köklendirilmesinde, en yüksek köklenmenin să̆landiğı ortam, bitkicik başına 16,5 adet kök ile 1,0 mg $l^{-1}$ IBA+2,0 $m g l^{-1} J A$ içeren MS ortamında bulunmuştur. Bitkiciklerin bulb çapları incelendiğinde ise en iyi bulb gelişiminin 4,19 mm bulb çapı artış ortalamastyla 1,0 $\mathrm{mg} \mathrm{l}^{-1} I B A+0,2 \mathrm{mg} \mathrm{l}^{-1} \mathrm{NAA}+2,0 \mathrm{mg} \mathrm{l}^{-1} \mathrm{JA}$ ve 1,0 $\mathrm{mg} \mathrm{l}^{-1} \mathrm{IBA}$ içeren MS ortamlarından elde edildiği gözlenmiştir.
\end{abstract}

Anahtar Kelimeler: Iris sari Schott ex Baker, in vitro çoğaltım, köklendirme, JA, bulb oluşumu.

\section{In Vitro Multiplication and Rooting Studies of Iris sari Schott ex Baker}

ABSTRACT: Tissue culture techniques, one of the biotechnological applications for the protection of plant biodiversity, are often used especially in the protection of endemic plants. Iris sari Schott ex Baker, an endemic species of the family Iridaceae, has natural spreading areas in our country. The aim of our study is to investigate the vegetative multiplication and effective rooting possibilities of Iris sari Schott ex Baker, one of the geophytes of Turkey, with in vitro techniques. For this purpose, immature embryos belonging to the Iris sari Schott ex Baker, plant have been used as initial explant. Rooting studies were done with shoots obtained as a result of in vitro proliferation studies. As a result of the studies,

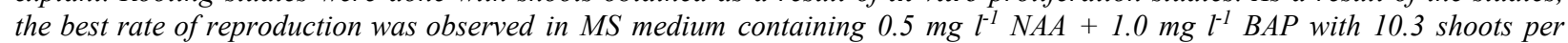
explant. In rooting of proliferated plantlets, the medium in which the highest rooting is achieved was found in MS medium containing $1.0 \mathrm{mg} \mathrm{l}^{-1} \mathrm{IBA}+2.0 \mathrm{mg} \mathrm{l}^{-1} \mathrm{JA}$ with 16.5 roots per plant. When the bulb diameters of plantlets were examined, it was observed that the best bulb development was achieved from MS medium containing $1.0 \mathrm{mg}^{-1} \mathrm{IBA}+0.2 \mathrm{mg} l^{-1} \mathrm{NAA}+2.0 \mathrm{mg}$ $l^{-1} J A$ and $1.0 \mathrm{mg} \mathrm{l}^{-1} \mathrm{IBA}$ with a bulb diameter increase average of $4.19 \mathrm{~mm}$.

Keywords; Iris sari Schott ex Baker, in vitro propagation, rooting, JA, bulb formation. 


\section{GíRiş}

Ülkemizin sahip olduğu zengin bitki biyoçeşitlilik, doğal tahribatlar, bilinçsiz kentleşme, iklim değişiklikleri gibi başlıca sebeplerle tehlike altındadır. Öyle ki, yapılan çalışmalar doğrultusunda, 6000'den fazla sayıda endemik bitki türünü bünyesinde barındıran Akdeniz havzasında önemli oranda genetik erozyon yaşandığ 1 bildirilmektedir (Tan, 1996; Dağcı ve ark., 2002, Yılmaz-Gökdoğan ve Kaya, 2017). Ülkemiz doğal florasında yetişmekte ve endemizm oranı yüksek olan Iris L. cinsleri üzerinde çok fazla çalışma bulunmamaktadır. Bitkisel zenginliğimizin korunması ve sürdürülebilirliğinin sağlanması, bununla birlikte bitki 1slahı çalışmaları ile de ülke ekonomisine destek sağlamak amaciyla bu konudaki bilimsel çalışmaların arttırılması gerekmektedir.

Iridaceae familyası dünyada yaklaşık 80 cins ve 2315 tür ile temsil edilmektedir (Anonymous, 2019). Ülkemizde ise 23'ü endemik olmak üzere 56 takson ile temsil edilen Iridaceae familyası geniş bir bitki genetik çeşitliliğini sergilemektedir (Güner, 2012; Erken ve ark., 2009; Doğan ve Çağlar, 2018). Süs bitkisi olarak kullanım potansiyelinin yanında İris türleri genellikle ilaç sanayide ve kozmetik endüstrisinde yaygın olarak kullanılmaktadır (Wang ve ark., 1999; Jevremović ve Radojević, 2002; Al-Gabbiesh ve ark., 2006; Francescangeli, 2009; Nasircilar ve Deniz, 2014; Doğan ve Çă̆lar, 2018).

I. sari Schott ex Baker halk arasinda 'Ana kurtkulağ1, Bahar çiçeği' olarak da bilinmektedir. Iris sari, İran-Turan floristik bölgesine ait bir türdür. Türkiye'de doğal yayılışı Doğu, İç, Güney Anadolu ve Doğu Karadeniz bölgeleri olan I. sari, Gaziantep, Çankırı, Amasya, Elazı̆̆, Erzurum, Kayseri, Niğde, Bayburt illerinde, 900-2700 rakımlı bölgelerde yetişen rizomlu ve endemik bir bitki türüdür. Oncocyclus altcinsi içerisinde incelenen Iris sari, çok yıllık bir bitki olup, NisanHaziran ayları arasında çiçeklenme göstermektedir. Çiçeklerinin soluk sarı taç yaprakları ve pembeden kahverengiye çalan kan kırmızı yoğun damarları olan, sarı sakallı, derin kırmızıdan kahverengiye doğru lekelerle soluk sarı renge sahip firfırlı çanak yaprakları ile süs bitkisi potansiyeli yüksek olan gösterişli bir bitkidir.

İris türlerinin bazıları rizomlarının ayrılmasıyla, bazıları ise soğanlarının çoğaltılmasıyla vejetatif olarak üretilmektedir. Geofit bitkilerin çoğunda olduğu gibi, bazı soğanlı irisler de yılda 5 'ten fazla soğan üretimi gerçekleştirememekte, rizomlu türler ise rizomların ayrılma tekniğiyle yılda en fazla 10 bitkicik vermektedir (Je'han ve ark., 1994). Ayrıca, zayıf meyve oluşumu yüzünden oldukça az meydana gelen tohumların çimlenmesi oldukça zordur ve tohumların çiçeğe dönüşmesi uzun zaman almaktadır (Simonet, 1932).

Bitki 1slahı sektöründe biyoteknolojik tekniklerin uygulanabilirliği, konu uzmanlarının çalışmalarına ivme kazandırmaktadır. Bunlardan biri olan in vitro çoğaltım çalışmaları da başlangıç islah materyali eldesinde oldukça önemli bir adım olarak bilinmektedir. Bitki doku kültürü tekniği, özellikle nadir ve endemik bitki türlerinin orta süreli korunmasında, ayrıca geleneksel yöntemlerle çoğaltımı zor olan bitki türlerinin çoğaltımında güçlü bir alternatif yöntem olarak karşımıza çıkmaktadır. In vitro mikroçoğaltım çalışmalarıyla bitki üretimi, sınırlı bir zaman aralığında çok sayıda bitkicik eldesi için oldukça hızlı ve kolay yöntemlerden birisi durumundadır (Bhojwani ve Razdan, 1996; Thomas, 2007). Birçok geofit bitki türünde (Lilium longiflorum, Narcissus confusus, Fritillaria thunbergii, Allium sativum, Sternbergia fischeriana, Gerbera jamesonii), soğan, soğan pulları, yaprak, gövde parçaları gibi kısımların eksplant kaynağ1 olarak kullanıldığ 1 in vitro çoğaltım çalışmaları mevcuttur (Selles ve ark., 1999; Nhut ve ark., 2002; Paek ve Murthy, 2002; Aswath ve ark., 2003; Kim ve ark., 2003). İris bitkisinde ilk mikro çoğaltım embriyo kurtarma çalışması ile başlamıştır (Randolph, 1945). Yine İrislerde apikal meristem kültürü ile ilk üretim Baruch ve Quak (1966), tarafından başarıyla gerçekleştirilmiştir. Hussey (1976), 0,5 $\mu \mathrm{M}$ BA kullanarak, Iris hollandica'da apikal dormansiyi kırıp çoklu sürgün geliştirmeyi sağlamış ve en iyi sürgün gelişimini $0,5 \mu \mathrm{M} \mathrm{BA}+5,4 \mu \mathrm{M}$ NAA kombinasyonunu kullanarak gövde ve soğan pullarından elde etmiştir. 
Uzun ve ark. (2016), Iris galatica ile yapmış oldukları çalışmada, bu bitki türü için çoğaltım protokolü oluşturmuşlardır. TDZ, BAP ve NAA bitki büyüme düzenleyicilerini içeren $\mathrm{MS}$ ortamında, olgunlaşmamış embriyolar ile in vitro şartlarda çoğaltılan bitkiciklerin yapraklarını kültüre almışlardır. Araştırıcılar, bu bitki türü için olgunlaşmamış embriyolardan $0,5 \mathrm{mg}^{-1} \mathrm{TDZ}+0,5$ mg $1^{-1}$ NAA içeren MS ortamında bitkicik başına 4,85 adet sürgün, yaprak ekplantlarından ise 1,0 $\mathrm{mg} \mathrm{l}^{-1} \mathrm{TDZ}+0,5 \mathrm{mg} \mathrm{l}^{-1}$ NAA içeren MS ortamında bitkicik başına 3,04 adet sürgün oluşumu elde etmişlerdir. Çoğaltılan bitkiciklerin en iyi köklenme oranını ise $1,0 \mathrm{mg} \mathrm{l}^{-1}$ IBA ya da $1,0 \mathrm{mg} \mathrm{l}^{-}$ ${ }^{1}$ NAA içeren ortamlarda sırasıyla $\% 48$ ve $\% 45$ oranında elde ettiklerini belirtmişlerdir. Laublin ve Cappadocia, (1992) I. pseudocorus, I. setosa ve I. versicolor genotiplerinin çiçeklerinden farklı eksplant tiplerini in vitro kültüre almışlardır. Ovaryum eksplantlanı düşük 1şı şiddeti altında gelişirken, en iyi kallus oluşumunu 4,5 $\mu \mathrm{M} 2.4 \mathrm{D}$ ya da 4,5 $\mu \mathrm{M} 2.4 \mathrm{D}+4,5 \mu \mathrm{M}$ Kinetin içeren besin ortamında gözlemlemişlerdir. Kallus ve meristematik bölgeleri $22 \mu \mathrm{M}$ BA içeren ortamda alt kültüre alarak rejenerasyonu sağlamışlardır.

Gozu ve ark. (1993), I. pallida' nın in vitro çoğaltımıyla ilgili bir çalışma yapmışlar ve kallustan bitkicikler elde etmişlerdir. Karanlık ortam şartlarında, $0,1 \mathrm{mg} \mathrm{l}^{-1}$ Kinetin ve $1,0 \mathrm{mg} \mathrm{l}^{-1}$ 2.4 D içeren LS (Linsmaier ve Skoog) ortamında, sadece yaprağın rizoma bağlantı bölgesinden alınan eksplantlarda sarı renkli kalluslar meydana geldiğini gözlemişlerdir.

Ancak, toprakaltı depo organlarının sebebiyet verdiği kontaminasyona çözüm olabilecek bir eksplant tipi olan, olgunlaşmamış embriyolarla ilgili sınırlı sayıda çalışmanın varlığı bilinmektedir. Geofit bitkilerde olgunlaşmamış embriyoları eksplant kaynağı olarak kullanarak etkili sürgün rejenerasyon çalışmalarını bazı türlerde yapan araştırıcıların yol gösterici bulguları mevcuttur (Mirici ve ark., 2005; Uranbey, 2010; Nasircilar ve ark., 2011). Uzun ve ark. (2014) tarafindan Iris sari ve I. schachtii bitki türlerinde yapılan çalışmada, ana bitkinin aşırı derecede doğadan sökümünü engellemek amaciyla da olgunlaşmamış embriyoların in vitro sürgün rejenerasyonunda uygun eksplant kaynağı olabileceği belirtilmiştir.

$\mathrm{Bu}$ sebeple, ülkemize endemik olan ve üzerinde çoğaltıma yönelik az çalışmanın mevcut olduğu Iris sari Schott ex Baker bitkisinde yapilan çalışmalar ilerideki ıslah çalışmaları için oldukça önemlidir.

$\mathrm{Bu}$ çalışmada, bitki doku kültürü teknikleriyle Iris sari bitkisinin olgunlaşmamış embriyoları başlangıç eksplantı olarak kullanılarak, çoğaltım, etkili köklenme ve bulb gelişiminin sağlanabilmesi amaçlanmıştır.

\section{MATERYAL ve METOT}

\section{Bitkisel materyal ve sterilizasyonu}

“Türkiye'nin Bazı Endemik Iris Türlerinde In vitro Rejenerasyon ve In vitro Poliploid Bitki Oluşturma Üzerine Araştırmalar" isimli doktora tez projesinin bir parçası olan çalışmada, başlangıç materyali olarak Kayseri-Sarı-Küçüksöbeçimen bölgesinden toplanan I. sari bitkisine ait tohumlar kapsülleri ile birlikte toplanmıştır (Mayıs, 2015). Kahramanmaraş Sütçü İmam Üniversitesi, Bahçe Bitkileri Bölümü, Biyoteknoloji Laboratuvarına getirilen bitki materyallerinin sterilizasyon işlemleri yapılmıştır.

Tohum kapsülleri dikkatli bir şekilde çıkartılan tohumların yüzey sterilizasyonu, ağzı kapaklı olan tel süzgeçler içerisine konularak akan çeşme suyu altında 1 saat yıkanmıştır. Ardından \% 0,2'lik fungusit (Benlate) çözeltisi içerisinde 30 dakika süre ile karıştırıcıda çalkalanmıştır. Beher içerisindeki fungusit süzülerek tohumlar saf su ile 2-3 defa yıkanmış, sonraki işlemler steril kabin içerisinde \% 70'lik etil alkolde 1 dakika süre ile bekletilerek devam etmiştir. Saf su ile alkolden arındırılan tohumlar, 20 dakika süre ile içerisinde 2 damla Tween 20 eklenen \% 20'lik $\mathrm{NaOCl}$ (Domestos) solüsyonunda bekletilmiş, ardından steril saf su ile 3 defa yıkanarak sterilizasyon ișlemi tamamlanmıştır. Yüzeyi deterjandan arındırılmış olan tohumlar bir pens yardımı ile whatman filtre kağıdı üzerine alınarak kurutulmuştur. 


\section{Kültür şartları}

Yüzey dezenfeksiyonu yapılmış tohumlardan olgunlaşmamış embriyolar steril kabin içerisinde pens ve bistüri yardımıyla embriyoya zarar vermeyecek şekilde çıkartılarak, hazırlanan besin ortamları içerisine hızlıca yerleştirilmiştir. Denemelerde kullanılan besin ortamlarının tümü MS (Murashige ve Skoog, 1962) tuzlarını içermekle birlikte $\% 3$ sukroz (w/v) ve ortamları katılaştırmak amacıyla \% 0,7 oranında agar (w/v) içermektedir. İçerisine bitki büyüme düzenleyicileri eklenen ve pH'1 5,7 olarak ayarlanan besin ortamları $121{ }^{\circ} \mathrm{C}$ 'de 20 dakika süreyle otoklav edilmiştir. Çoğaltım denemesinde içerisine yaklaşı $20 \mathrm{ml}$ besin ortamlarının dökülerek hazırlanan petri kapları (10x100 mm), köklendirme ve bulb geliştirme denemelerinde ise içerisine yaklaşık $40 \mathrm{ml}$ besin ortamlarının dökülerek hazırlandığı magenta kapları kullanılmıştır. Tüm uygulamalarda kullanilan eksplantlar, beyaz floresan 1şık (3000 lüx) ile aydınlatılan (16/8 saat aydınlık/karanlık) $24 \pm 1{ }^{\circ} \mathrm{C}$ iklim odalarında kültüre alınmıştır. Kültürler, her 6 haftanın sonunda aynı içeriğe sahip yeni besin ortamlarına aktarılmıştır. Sürgünlerin kardeşlenme, köklenme ve bulb gelişimleri 2 alt kültür sonunda gözlemlenmiştir.

\section{Kültüre alma ve çoğaltım çalışmaları}

\section{Olgunlaşmamış embriyolardan bitki geliştirme ve kardeşlenme denemesi}

Olgunlaşmamış embriyolardan bitki geliştirme ve bu bitkilerde kardeşlenme üzerine TDZ (Thidiazuran), NAA (Naftalenasetik asit) ve BAP (Benzilaminopurin)'ın etkisi incelenmiştir. $\mathrm{Bu}$ amaçla in vitro şartlarda Iris sari Schott ex Baker bitkisine ait tohumlardan çıkartılan embriyolar, TDZ, NAA ve BAP'ın 4 farkl konsantrasyon ve kombinasyon $\left(1,0 \mathrm{mg} \mathrm{l}^{-1} \mathrm{TDZ}+0,5 \mathrm{mg}^{-1} \mathrm{NAA}\right.$; $0,5 \mathrm{mg} \mathrm{l}^{-1} \mathrm{TDZ}+0,5 \mathrm{mg} \mathrm{l}^{-1} \mathrm{NAA} ; 1,0 \mathrm{mg} \mathrm{l}^{-1} \mathrm{BAP}+$ $\left.0,5 \mathrm{mg} \mathrm{l}^{-1} \mathrm{NAA} ; 4,0 \mathrm{mg} \mathrm{l}^{-1} \mathrm{BAP}\right)$ içeren $\mathrm{MS}$ ortamlarında kültüre alınmıştır. Denemede petri kapları kullanılmış olup, her bir uygulama için 3'er tekerrür, her tekrarda 4'er eksplant (embriyo) olacak şekilde, eksplantlar kültüre alınmıştır.

\section{Kardeşlenme ve kök oluşturma denemesi}

Olgunlaşmamış embriyolardan geliştirilerek alt kültürde çoğaltılan sürgünlerde kardeşlenme ile birlikte köklenme üzerine TDZ, NAA ve IAA ile farklı konsantrasyonlardaki kombinasyonlarının etkisi incelenmiştir. Yaklaşık 2,5 cm uzunluğa ulaşan köklenmemiş $I$. sari sürgünleri TDZ $(0,0$; 0,$\left.5 ; 1,0 \mathrm{mg} \mathrm{l}^{-1}\right)$, NAA $\left(0,0 ; 0,5 \mathrm{mg}^{-1}\right)$, IAA $(0,0$; $\left.0,5 \mathrm{mg} \mathrm{l}^{-1}\right)$ ve JA $\left(0,0 ; 2,0 \mathrm{mg} \mathrm{l}^{-1}\right)$ içeren 12 farklı MS ortamında kültüre alınmışlardır. Kontrol ortamına ise bitki büyüme düzenleyici (BBD) ilavesi yapılmamıştır. Denemede, kontrol grubu dahil olmak üzere, magenta kapları kullanılmış olup, her bir uygulama için 3'er tekerrür, her tekrarda 3'er eksplant (sürgün) olacak şekilde, eksplantlar kültüre alınmıştır.

\section{Köklenme ve bulb gelişimi denemesi}

Iris sari bitkisine ait olgunlaşmamış embriyolardan geliştirilerek alt kültürde çoğaltılan eksplantlarda, sürgünlerin bulb gelişimini gözlemlemek amaciyla, yaklaşık $2,5 \mathrm{~cm}$ uzunluğa ulaşan köklenmemiş $I$. sari sürgünleri IBA $\left(0,0\right.$ ve $\left.1,0 \mathrm{mg} \mathrm{l}^{-1}\right)$, NAA $(0,0$; 0,2 ve $\left.0,4 \mathrm{mg} \mathrm{l}^{-1}\right)$ ve JA $\left(0,0\right.$ ve $\left.2,0 \mathrm{mg} \mathrm{l}^{-1}\right)$ içeren 6 farklı MS ortamında kültüre alınmışlardır. Kontrol ortamına ise bitki büyüme düzenleyici (BBD) ilavesi yapılmamıştır. Denemede, kontrol grubu dahil olmak üzere, magenta kapları kullanılmış olup, her bir uygulama için 3'er tekerrür, her tekrarda 3'er eksplant (sürgün) olacak şekilde, eksplantlar kültüre alınmıştır.

Altı farklı içeriğe sahip besin ortamında kültüre alınacak bitkicik eksplantlarının başlangıç bulb çapları (ilk ölçüm) ölçülerek kültüre alınmış ve 2 alt kültür sonunda da bulb çapları (son ölçüm) tekrar ölçülerek gelişmeleri kaydedilmiştir.

\section{İstatistiksel analizler}

In vitro çoğaltım çalışmalarının tüm denemeleri Tesadüf Parselleri Deneme Desenine (TPDD) göre düzenlenmiştir. Çalışmada, elde edilen gözlem ve ölçüm sonuçlarına ilişkin verilerin değerlendirmesi amacıyla, MS Excel programı kullanılmıştır. In vitro çalışmalar sonucunda elde edilen verilerin analizleri JMP 8.0 kullanılarak yapılmıştır. Yüzde 
verileri için açı transformasyon değerleri hesaplanmıştır. Sonuçlarının değerlendirilmesinde ve ortalamaların karşılaştırmasında varyans analizi ve LSD testi uygulanmıştır (Steel ve Torrie, 1980; Yurtsever, 1984).

\section{BULGULAR ve TARTIŞMA}

\section{Bitki oluşturma ve kardeşlenme denemesi bulguları}

In vitro şartlarda Iris sari bitkisine ait olgunlaşmamış embriyolarla çoğaltım denemeleri kurulmuş, en iyi sürgün gelişim ortamı belirlenmiştir.

Elde edilen bulgular doğrultusunda, eksplant başına düşen sürgün sayısı bakımından incelenen farklı besin ortamı içeriklerinin sürgün sayısı oluşumuna etkisi, istatistiksel olarak $(\mathrm{p} \leq 0,05)$ önemsiz olmakla birlikte, göreceli olarak en iyi kardeşlenme $1,0 \mathrm{mg} \mathrm{l}^{-1} \mathrm{BA}+0,5 \mathrm{mg} \mathrm{l}^{-1} \mathrm{NAA}$ (3 no'lu ortam) içeren besin ortamında 10,3 adet/ eksplant olarak gözlenmiştir. Farklı besin ortamı içeriklerinin, sürgünlerin kardeşlenme oranı (\%) üzerindeki etkisinin istatistiki anlamda önemlilik gösterdiği, en iyi oranın \% 75 ile 3 no'lu ortamda elde edilmiştir (Çizelge 1 ve Şekil 1). Iris sari sürgününün in vitro koşullardaki gelişimi Şekil 2'de görülmektedir.

Bitki büyüme düzenleyicilerden olan sitokininler, çeşitli bitki eksplant tipleri üzerinde, sürgün rejenerasyonu için genel olarak kullanılmaktadır (Kancherla ve Bhalla, 2003). BA, doğal bir sitokinin grubu büyüme düzenleyicisi olup, yaygın olarak organogenesisi teşvik etmek amaciyla s1klıkla tercih edilmektedir. Diğer taraftan, doğal olmayan bir sitokinin olan TDZ'nin ise çoklu sürgün çoğaltımı amacıyla kullanıldığı belirtilmiştir (De Gyves ve ark., 2001; Kancherla ve Bhalla, 2003).

Uzun ve ark. (2014), Iris sari bitkisine ait embriyolarla yaptıkları çoğaltım çalışmalarında TDZ ve NAA kombinasyonlarının sürgünlerin kardeşlenmesinde etkili olduğunu belirtmişlerdir. En yüksek kardeşlenme oranını \% 96,88 ile 0,5 mg $1^{-1} \mathrm{TDZ}+0,5 \mathrm{mg}^{-1}$ NAA içeren MS ortamında, eksplant başına düşen sürgün sayısını 9,55 adet olarak gözlemlemişlerdir. $\mathrm{Bu}$ çalışmada, aynı içeriğe sahip MS ortamında kardeşlenme gösteren embriyo yüzdesi \% 25 ve kardeş sayısı 6,0 adet olarak belirlenmiştir.

Aynı şekilde Uzun ve ark. (2016), Iris galatica ile yapmış oldukları çalışmada, olgunlaşmamış embriyolardan $0,5 \mathrm{mg} \mathrm{l}^{-1} \mathrm{TDZ}+0,5 \mathrm{mg} \mathrm{l}^{-1} \mathrm{NAA}$ içeren MS ortamında bitkicik başına 4,85 adet sürgün elde ettiklerini belirtmişlerdir. Boltenkov ve Zarembo (2005), bitki türlerinin ve bitki büyüme düzenleyicilerinin rejenerasyonun sağlanmasında önemli rolünün olduğunu belirtmektedir. Benzer şekilde, Uzun ve ark. (2014), besin ortamları değişmeksizin aynı bitki türlerinin rejenerasyona verdikleri farklı tepkilerin, bitki büyüme düzenleyici konsantrasyon ve kombinasyonlarının ve hatta bitki genotiplerinin bile etkili olacağını ve farklılıkların bunlardan kaynaklanabileceğini belirtmişlerdir. Bununla birlikte, bitkinin habitatı, bitki materyalinin toplanma zamanı, bitki yaş1, kültüre alma koşulları da rejenerasyonu etkileyen faktörler arasında görülmektedir.

Çizelge 1. MS ortamına ilave edilen TDZ, NAA ve BAP'ın Iris sari'de sürgün sayısı üzerine etkisi. Table 1. Effect of TDZ, NAA and BAP added to MS medium on shoot number in Iris sari.

\begin{tabular}{|c|c|c|c|c|}
\hline \multirow[b]{2}{*}{ No } & \multirow{2}{*}{$\begin{array}{l}\text { Bitki büyüme düzenleyici konsantrasyon } \\
\text { ve kombinasyonları }\left(\mathrm{mg} \mathrm{l}^{-1}\right) \\
\text { Plant growth regulators consantrations } \\
\text { and combinations }\left(\mathrm{mg} \mathrm{l}^{-1}\right)\end{array}$} & \multirow{2}{*}{$\begin{array}{c}\text { Sürgün say1s1 } \\
\text { (adet/eksplant) } \\
\text { Number of shoots } \\
\text { (number/explant) } \psi\end{array}$} & \multicolumn{2}{|c|}{$\begin{array}{l}\text { Sürgün oluşturma oranı (\%) } \\
\text { Shooting rate }(\%)\end{array}$} \\
\hline & & & $\%$ & $\begin{array}{c}\text { içı trasformasyonu değeri } \\
\text { Angle transformation } \\
\text { valuue } \S\end{array}$ \\
\hline 1 & $1,0 \mathrm{TDZ}+0,5 \mathrm{NAA}$ & 7,00 & 58,33 & $50,00 \quad \mathrm{ab}$ \\
\hline 2 & $0,5 \mathrm{TDZ}+0,5 \mathrm{NAA}$ & 6,00 & 25,00 & 30,00 \\
\hline 3 & $1,0 \mathrm{BAP}+0,5 \mathrm{NAA}$ & 10,30 & 75,00 & 65,00 \\
\hline \multirow[t]{2}{*}{4} & $4,0 \mathrm{BAP}$ & 5,30 & 33,33 & 35,00 \\
\hline & $\operatorname{LSD}(\alpha: 0,05)$ & Ö.D. & & 20,45 \\
\hline
\end{tabular}

§Aynı harfle gösterilen ortalamalar arasında önemli fark $(\mathrm{P} \leq 0,05)$ yoktur (Same letters in a column are not significantly different at the 0.05 probability levels).

$\psi$ Ö.D. (N.S.): Önemli değil (Non-significant). 


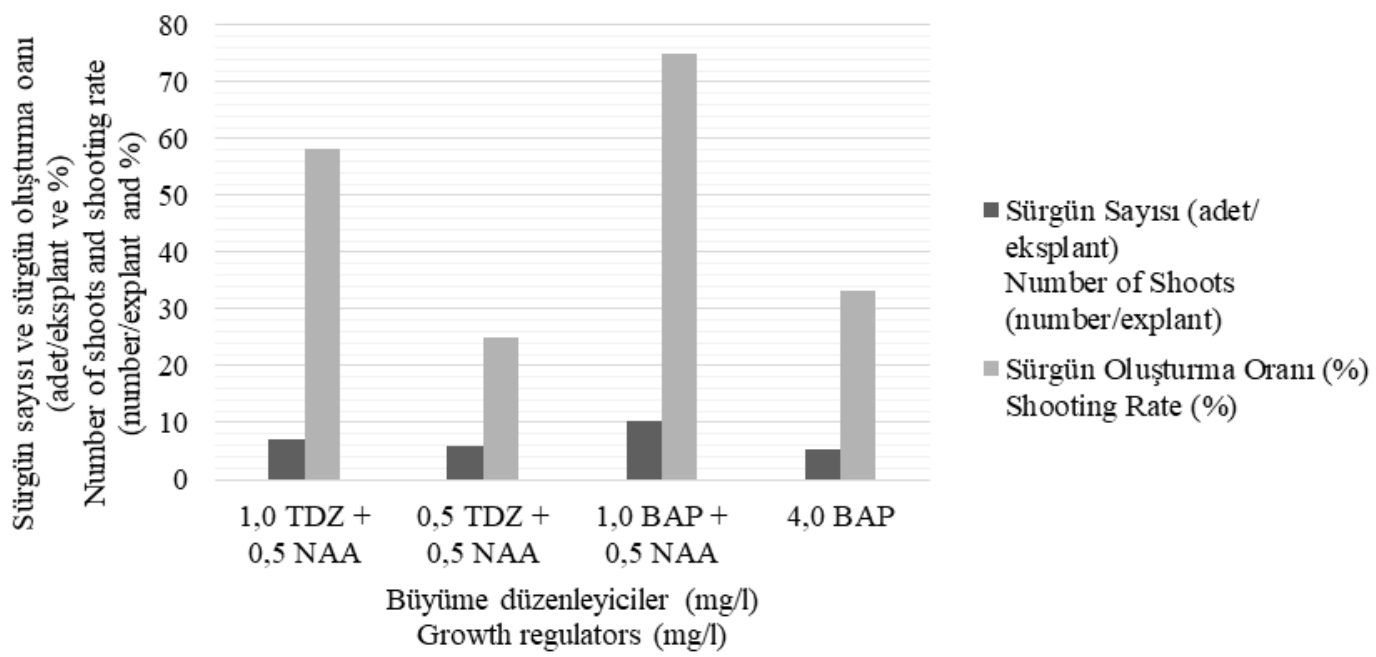

Şekil 1. Farklı büyüme düzenleyiciler eklenen MS ortamında Iris sari olgunlaşmamış embriyolarından sürgün rejenerasyonu. Figure 1. Shoots regeneration from immature embryos of Iris sari on MS medium supplemented with different concentrations of growth regulators.

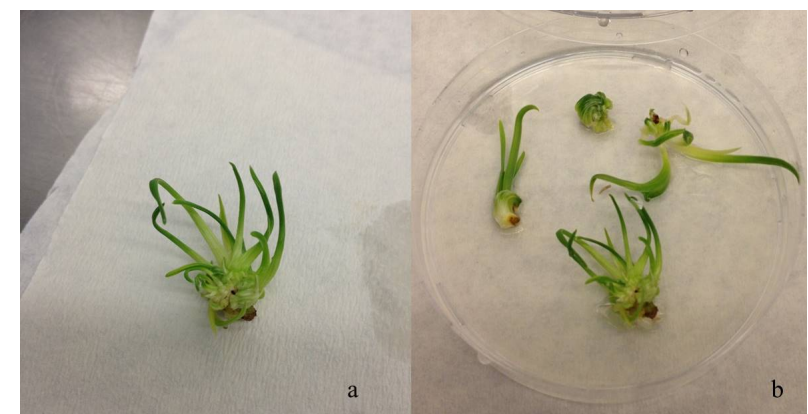

Şekil 2. Iris sari bitkisinin $0,5 \mathrm{mg} \mathrm{l}^{-1} \mathrm{NAA}+1,0 \mathrm{mg}^{-1} \mathrm{BAP}$ eklenen MS ortamında sürgün gelişimi.

Figure 2. Shoot development from immature embryos of Iris sari on $0,5 \mathrm{mg} \mathrm{l}^{-1} \mathrm{NAA}+1,0 \mathrm{mg} \mathrm{l}^{-1} \mathrm{BAP}$ added MS medium.

\section{Kardeșlenme ve köklenme denemesi bulguları}

Iris sari bitkisine ait olgunlaşmamış embriyolar, yapılan başlangıç çoğaltım çalışmaları sonucunda belirlenen ve en iyi sürgün rejenerasyonunun sağlanmış olduğu, 1,0 $\mathrm{mg} \mathrm{l}^{-1} \mathrm{BA}+0,5 \mathrm{mg}^{-1} \mathrm{NAA}$ içeren MS ortamlarında kültüre alınmıştır. Eksplantların 6 hafta süre ile büyümeleri sağlanan ve boyları $2,5 \mathrm{~cm}$ uzunluğa ulaşan köksüz I. sari sürgünleri TDZ, NAA, IAA ve JA içeren 12 farklı MS ortamına aktarılmışlardır. $\mathrm{Bu}$ ortamlar üzerinde gelişen, sürgün rejenerasyonu sağlayan ve kök oluşturan bitkicikler belirlenmiştir. Elde edilen bulgular istatistiksel olarak $(\mathrm{p} \leq 0,05)$ önemli olmakla birlikte, Çizelge 2 ve Şekil 3'te de görüldüğü gibi sürgün sayısı bakımından 3,96 adet/eksplant ile $1,0 \mathrm{mg} \mathrm{l}^{-1} \mathrm{TDZ}+0,5 \mathrm{mg} \mathrm{l}^{-1} \mathrm{NAA}$ içeren MS ortamı en başarılı bulunurken, aynı ortamın \% 88,86 köklenme oranı ve kök sayıs1 3,16 adet/eksplant ile en iyi oranlara sahip olduğu görülmektedir. Bu çalışmada köklenme oranının \% 100 olduğu $1,0 \mathrm{mg} \mathrm{l}^{-1} \mathrm{TDZ}+2,0 \mathrm{mgl}^{-1} \mathrm{JA}$ içeren ortamdaki bitkiciklerin kök sayısı 2,26 kök/eksplant olarak belirlenirken, bu ortamda kardeş sayısı 2,1 adet/eksplant olarak bulunmuştur. En düşük kök sayısı 0.3 adet/eksplant ile kontrol grubu bitkiciklerinde gözlenmiş, yine kontrol grubu bitkiciklerinde kardeş sayısı da 1,2 adet/ eksplant ile en düşük oran olarak bulunmuştur. TDZ, NAA ve IAA'nın JA ile kombinasyonlarını içeren MS ortamları sürgün sayısı, köklenme oranı ve kök sayısı bakımından incelendiğinde elde edilen bulguların JA içermeyen ortamlara göre üstün olduğu görülmemektedir. Elde edilen veriler doğrultusunda doğru kombinasyonu sağlanan bitki büyüme düzenleyicilerin etkisinin, köklenme üzerinde daha iyi sonuçları sağladığı görülmektedir. TDZ + IAA'ya göre TDZ + NAA kombinasyonunun dengeli konsantrasyonları sağlandığında (5 ve 11 no'lu ortamlardaki gibi) köklenme sayısı bakımından daha iyi sonuçlar verdiği gözlenmiștir. JA'nın köklenme üzerindeki etkisini görmek amaciyla JA'nın uygulamalardaki konsantrasyonlarının daha düşük ve daha yüksek oranları ile birlikte kullanılması, ayrıca BA kombinasyonlarının da yapılması gerektiği düşünülmektedir. 
Çizelge 2.MS ortamına ilave edilen TDZ, NAA, IAA ve JA'in Iris sari'de kök sayısı, köklenme oranı ve sürgün rejenerasyonu üzerine etkisi.

Table 2. Effect of TDZ, NAA, IAA and JA added to MS medium on root number, root rate and shoots regeneration in Iris sari.

\begin{tabular}{|c|c|c|c|c|c|c|c|c|}
\hline \multirow[b]{2}{*}{ No } & \multirow{2}{*}{$\begin{array}{l}\text { Bitki büyüme düzenleyici, } \\
\text { Konsantrasyon ve kombinasyonları } \\
\left(\mathrm{mg} \mathrm{l}^{-1}\right) \\
\text { Plant growth regulators } \\
\text { Consantrations and combinations } \\
\left(\mathrm{mg} \mathrm{l}^{-1}\right)\end{array}$} & \multirow{2}{*}{\multicolumn{2}{|c|}{$\begin{array}{c}\text { Kök say1s1 } \\
\text { (adet/eksplant) } \\
\text { Number of } \\
\text { roots } \\
\text { (number/explant)§ }\end{array}$}} & \multicolumn{3}{|c|}{$\begin{array}{l}\text { Köklenme oranı }(\%) \\
\text { Rooting rate }(\%)\end{array}$} & \multirow{2}{*}{\multicolumn{2}{|c|}{$\begin{array}{c}\text { Sürgün say1s1 } \\
\text { (adet/eksplant) } \\
\text { Number of shoots } \\
\text { (number/explant)§ }\end{array}$}} \\
\hline & & & & $\%$ & \multicolumn{2}{|c|}{$\begin{array}{l}\text { Açı trasformasyonu } \\
\text { değeri } \\
\text { Angle transformation } \\
\text { value } \S\end{array}$} & & \\
\hline 1 & $0,5 \mathrm{TDZ}$ & 2,30 & $a b c$ & 66.66 & 60,00 & abc & 2,40 & abc \\
\hline 2 & $0,5 \mathrm{TDZ}+0,5 \mathrm{NAA}$ & 0,86 & bc & 44.40 & 41,72 & bc & 2,06 & bc \\
\hline 3 & $0,5 \mathrm{TDZ}+0,5 \mathrm{IAA}$ & 2,53 & $a b$ & 77.73 & 66,46 & $a b c$ & 1,76 & $\mathrm{bc}$ \\
\hline 4 & $1,0 \mathrm{TDZ}$ & 1,30 & $a b c$ & 44.40 & 41,72 & bc & 2,30 & $a b c$ \\
\hline 5 & $1,0 \mathrm{TDZ}+0,5 \mathrm{NAA}$ & 3,16 & $\mathrm{a}$ & 88.86 & 78,23 & $\mathrm{ab}$ & 3,96 & $\mathrm{a}$ \\
\hline 6 & $1,0 \mathrm{TDZ}+0,5 \mathrm{IAA}$ & 1,1 & $a b c$ & 66.60 & 54,69 & $a b c$ & 1,93 & $\mathrm{bc}$ \\
\hline 7 & $0,5 \mathrm{TDZ}+2,0 \mathrm{JA}$ & 0,76 & $\mathrm{bc}$ & 33.30 & 29,98 & c & 1,76 & $\mathrm{bc}$ \\
\hline 8 & $0,5 \mathrm{TDZ}+0,5 \mathrm{NAA}+2,0 \mathrm{JA}$ & 1,73 & $a b c$ & 55.53 & 53,49 & $a b c$ & 1,63 & $\mathrm{bc}$ \\
\hline 9 & $0,5 \mathrm{TDZ}+0,5 \mathrm{IAA}+2,0 \mathrm{JA}$ & 1,83 & $a b c$ & 88.86 & 78,23 & $a b$ & 2,66 & $a b c$ \\
\hline 10 & $1,0 \mathrm{TDZ}+2,0 \mathrm{JA}$ & 2,26 & $a b c$ & 100.0 & 90,0 & $\mathrm{a}$ & 2,10 & $\mathrm{bc}$ \\
\hline 11 & $1,0 \mathrm{TDZ}+0,5 \mathrm{NAA}+2,0 \mathrm{JA}$ & 2,63 & $a b$ & 88.86 & 78,23 & $a b$ & 2,70 & $a b c$ \\
\hline 12 & $1,0 \mathrm{TDZ}+0,5 \mathrm{IAA}+2,0 \mathrm{JA}$ & 2,43 & $a b c$ & 77.73 & 66,46 & $a b c$ & 3,10 & $a b$ \\
\hline 13 & Kontrol & 0,30 & $\mathrm{c}$ & 33.30 & 29,98 & $\mathrm{c}$ & 1,20 & $\mathrm{c}$ \\
\hline
\end{tabular}

§Aynı harfle gösterilen ortalamalar arasında önemli fark $(\mathrm{P} \leq 0,05)$ yoktur (Same letters in a column are not significantly different at the 0.05 probability levels).

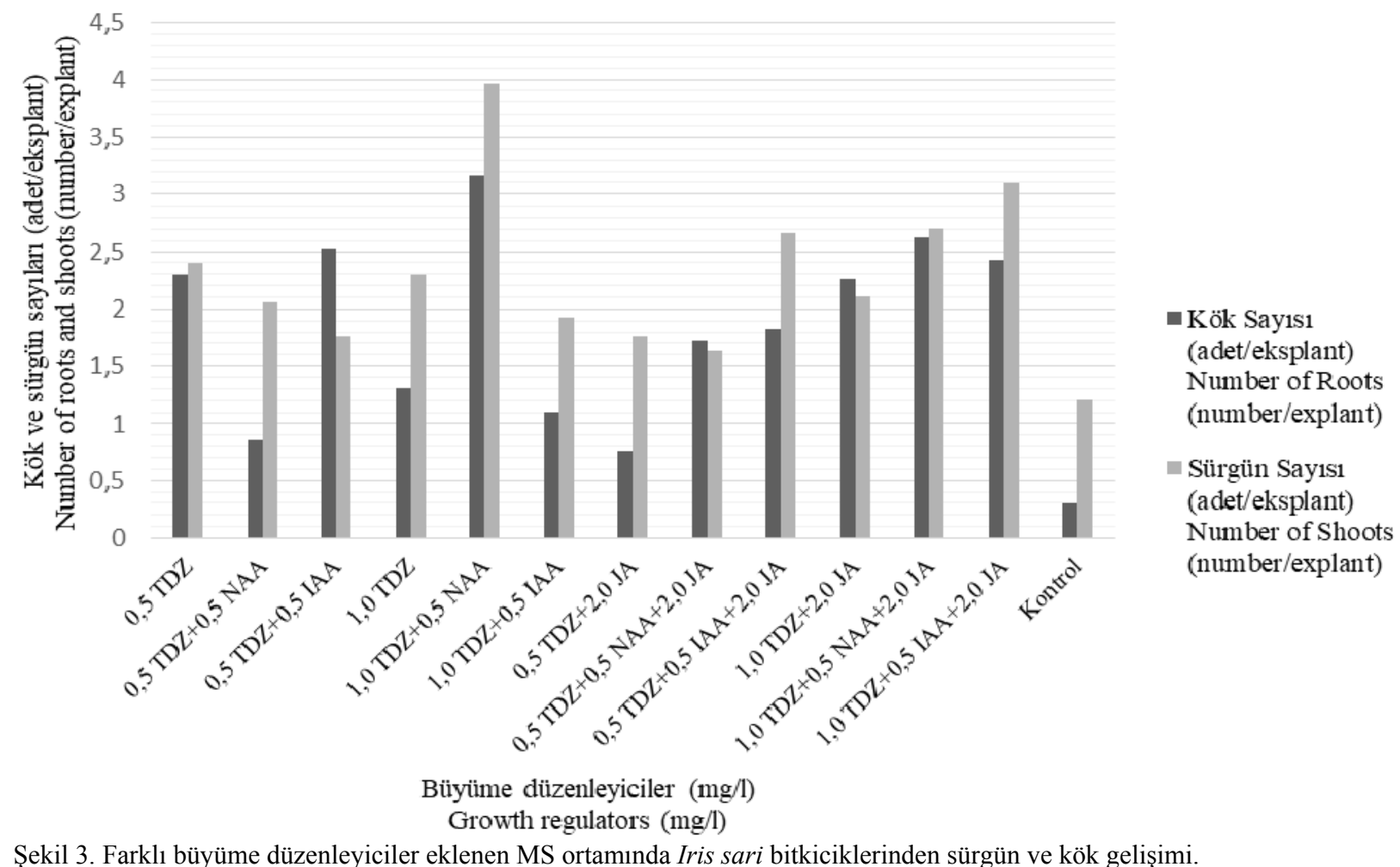

Figure 3. Shoots and root development from plantlets of Iris sari on MS medium supplemented with different concentrations of growth regulators. 


\section{Bulb gelişimi, köklenme ve kardeşlenme denemesi bulguları}

Iris sari bitkisine ait olgunlaşmamış embriyolar, yapılan başlangıç çoğaltım çalışmalarında en iyi sürgün rejenerasyonunu gösteren $1,0 \mathrm{mg} \mathrm{l}^{-1} \mathrm{BA}+$ $0,5 \mathrm{mg} \mathrm{l}^{-1} \mathrm{NAA}$ içeren MS ortamlarında kültüre alınmıştır. Kültüre alınan eksplantların 6 hafta süre ile büyümeleri sağlanmış ve boyları $2,5 \mathrm{~cm}$ uzunluğa ulaşan $I$. sari sürgünleri, NAA, IBA ve JA içeren 6 farklı MS ortamına aktarılmışlardır. $\mathrm{Bu}$ ortamlar üzerinde gelişerek kök oluşumları, bulb çapları ve sürgün rejenerasyonu sağlanan bitkicikler belirlenmiştir. Çizelge 3 ve Şekil 5'te de görüldüğg̈ gibi 6 farklı besin ortamı içerisindeki bitki gelişimleri incelendiğinde, en iyi kök gelișiminin, \% 100 köklenme oran1 ve sürgün başına düşen 16,5 kök/eksplant kök oluşumu ile 1,0 $\mathrm{mg} \mathrm{l}^{-1} \mathrm{IBA}+$ 2,0 $\mathrm{mg} \mathrm{l}^{-1} \mathrm{JA}$ içeren MS ortamından elde edildiği görülmektedir. JA ile kombinasyonlarının olduğu NAA-IBA bitki büyüme düzenleyicilerini içeren tüm MS ortamlarında \% 100 köklenme oranı gözlenmiştir. Aynı zamanda kök sayısı bakımından, JA kombinasyonunu içeren $1,0 \mathrm{mg} \mathrm{l}^{-1} \mathrm{IBA}+0,2$ $\mathrm{mg} \mathrm{l} \mathrm{l}^{-1} \mathrm{NAA}+2,0 \mathrm{mg} \mathrm{l}^{-1} \mathrm{JA}$ ve $1,0 \mathrm{mg} \mathrm{l}^{-1} \mathrm{IBA}+0,4$ $\mathrm{mg} \mathrm{l}^{-1} \mathrm{NAA}+2,0 \mathrm{mg}^{-1} \mathrm{JA}$ ortamlarında da sirasılyla 11,33 ve 9,63 kök/eksplant kök oluşumu ile başarılı bulunmuştur (Çizelge 3 ve Şekil 4).

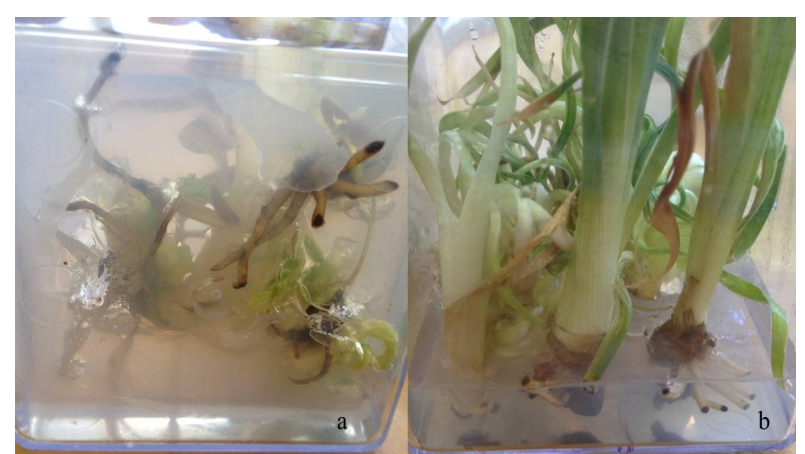

Şekil 4. Iris sari'nin 5 no'lu besin ortamında kök gelişimi (a-b). Figure 4. Root development of Iris sari nutrient medium number 5.

Bitkiciklere ait bulb çapı ölçümleri, ilk ölçüm, son ölçüm ve bu ölçümler arasındaki fark ile uygulamaların bulb çapı üzerindeki etkileri incelendiğinde, en iyi bulb çapı $1,0 \mathrm{mg}^{-1}$ IBA ve $1,0 \mathrm{IBA}+0,2 \mathrm{NAA}+2,0 \mathrm{JA}$ içeren $\mathrm{MS}$ ortamlarında 4,19 mm olarak tespit edilirken, Kontrol grubunda bu oran 2,54 mm olarak elde edilmiştir. Çizelge 3’te de görüldüğü üzere 1,5 ve
6 no'lu ortamlarda (1,0 IBA; 1,0 IBA + 0,2 NAA + 2,0 JA; 1,0 IBA + 0,4 NAA + 2,0 JA) bitkiciklere ait bulb çapı gelişimi üzerinde istatistiksel anlamda $(p \leq 0,05)$ önemlilik görülmemekle birlikte göreceli olarak olumlu yönde etkisi olduğu gözlenmiştir.

Sürgün rejenerasyonu bakımından incelenen eksplantlardaki gelişim BBD açısından istatistiksel olarak $(p \leq 0,05)$ önemsiz olmakla birlikte, en yüksek sürgün sayısı 3,4 adet/eksplant ile 1,0 $\mathrm{mg} \mathrm{l}^{-}$ ${ }^{1}$ IBA $+0,4 \mathrm{mg} \mathrm{l}^{-1}$ NAA içeren MS besin ortamı olarak bulunmuştur. Bununla birlikte elde edilen verilere göre JA kombinasyonlarını içeren NAAIBA kombinasyonlarının sürgün oluşumunu olumsuz yönde etkilediği görülmüş ve en düşük sürgün say1sı 1,3 sürgün/eksplant ile $1,0 \mathrm{mg} \mathrm{l}^{-1}$ $\mathrm{IBA}+0,2 \mathrm{mg} \mathrm{l}^{-1} \mathrm{NAA}+2,0 \mathrm{mg} \mathrm{l}^{-1} \mathrm{JA}$ içeren MS ortamında gözlenmiştir (Çizelge 3).

Santos ve Salema (2000), Narcissus triandrus bitkisinde yapmış oldukları in vitro çoğaltım çalışmasında, Jasmonik asitin 2 iP ve NAA ile kombinasyonlarını içeren besin ortamlarında kültüre aldıkları bitkiciklerin, soğan çaplarını ölçmüşler ve sadece JA içeren besin ortamlarında bulb çapının daha yüksek oranda olduğunu bildirmişlerdir.

JA içeren ortamlarda da bulb gelişim oranının yüksek olduğu, IBA, NAA ile doğru şekilde kombinasyonlarının sağlandığı uygulamalarda Jasmonik asitin köklenme ve bulb gelişimini teşvik edici olduğu değerlendirilebilinir (Çizelge 3).

Aynı zamanda, Şekil 6'da da görüldüğü gibi JA içeren besin ortamlarında gelișen bitkiciklerin köklerinde farklılaşmalar meydana geldiği gözlenmiştir. JA kullanımı sonucunda bitkiciklerin bulb çapındaki artışı aksine, kardeşlenme sayısında önemli derecede olmasa da azalma gözlenmiştir. Bununla birlikte, köklenme üzerine etkisi bilinen IBA ile yine aynı oksin grubuna ait BBD olan NAA kombinasyonlarının (2 ve 3 no'lu ortamlar) köklenme oranı üzerine önemli derecede etkisinin olmadığı, yalnız kullanılan IBA'nın köklenme oranı ve bulb gelişimi üzerinde daha etkili olduğu görülmektedir.

Uzun ve ark. (2014), I. sari bitkisiyle yapmış oldukları in vitro köklendirme çalışmasında $1,0 \mathrm{mg}$ $1^{-1}$ IBA ile $0,2 \mathrm{mg}^{-1}$ ve $0,4 \mathrm{mg} \mathrm{l}^{-1}$ NAA kombinasyonları uygulanan sürgünlerde elde 
edilen verilere göre, kök sayısı bakımından önemli derecede farklılık olmadığını görmüşlerdir. Araştırıcılar, en yüksek kök sayısını $0,1 \mathrm{mg} \mathrm{l}^{-1}$ IBA içeren MS besin ortamında 4,37 kök/eksplant olarak elde etmişlerdir. Bu çalışmada kullanılan aynı ortam içeriklerinde de birbirine yaklașık değerler elde edildiği, kök sayısının $1,0 \mathrm{mg}^{-1}$ IBA içeren besin ortamında 4,30 kök/eksplant olduğu belirlenmiştir.

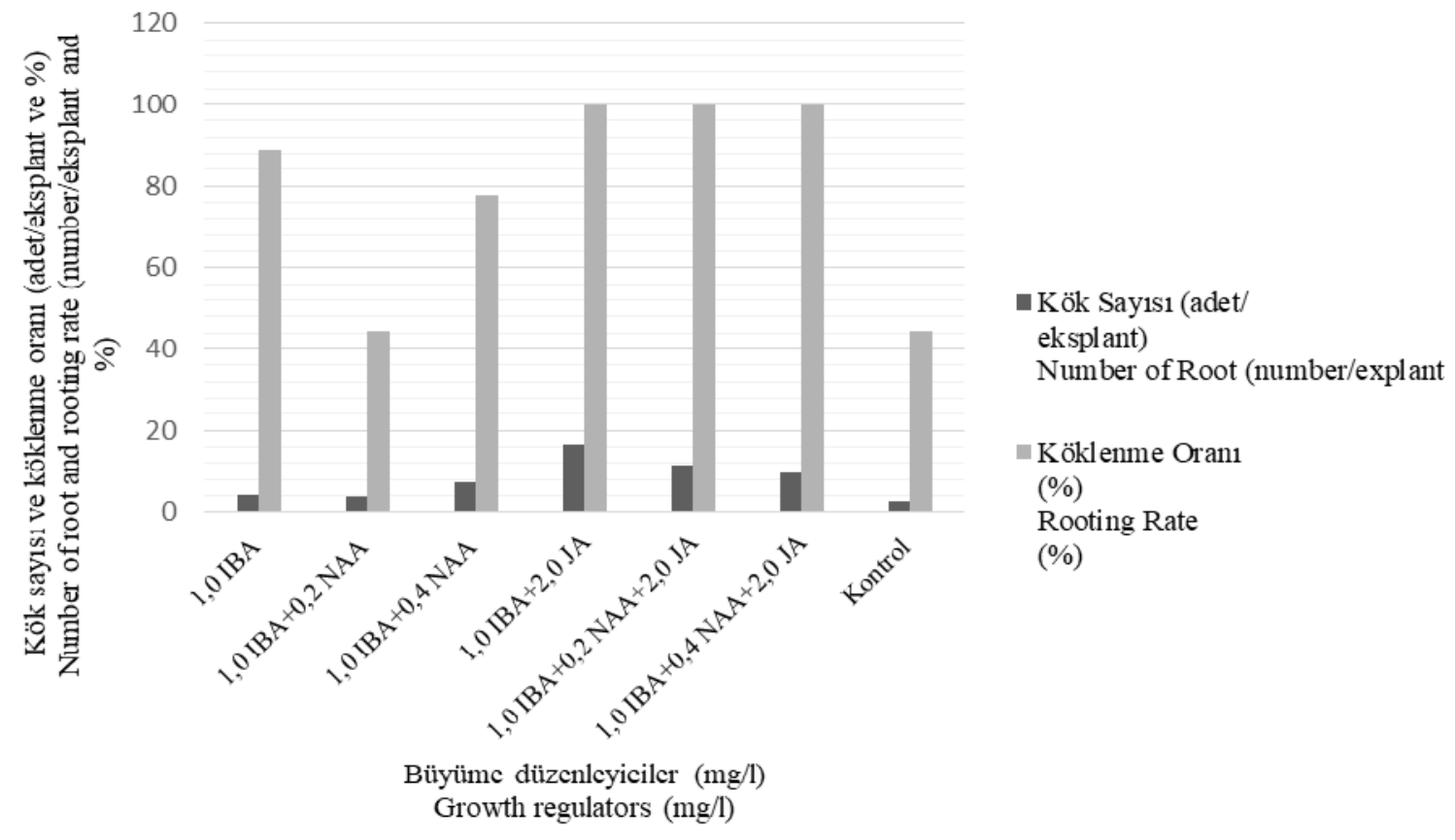

Şekil 5. Iris sari bitkisine ait kök sayısı ve köklenme oranları.

Figure 5. Number of roots and rooting rates of Iris sari.

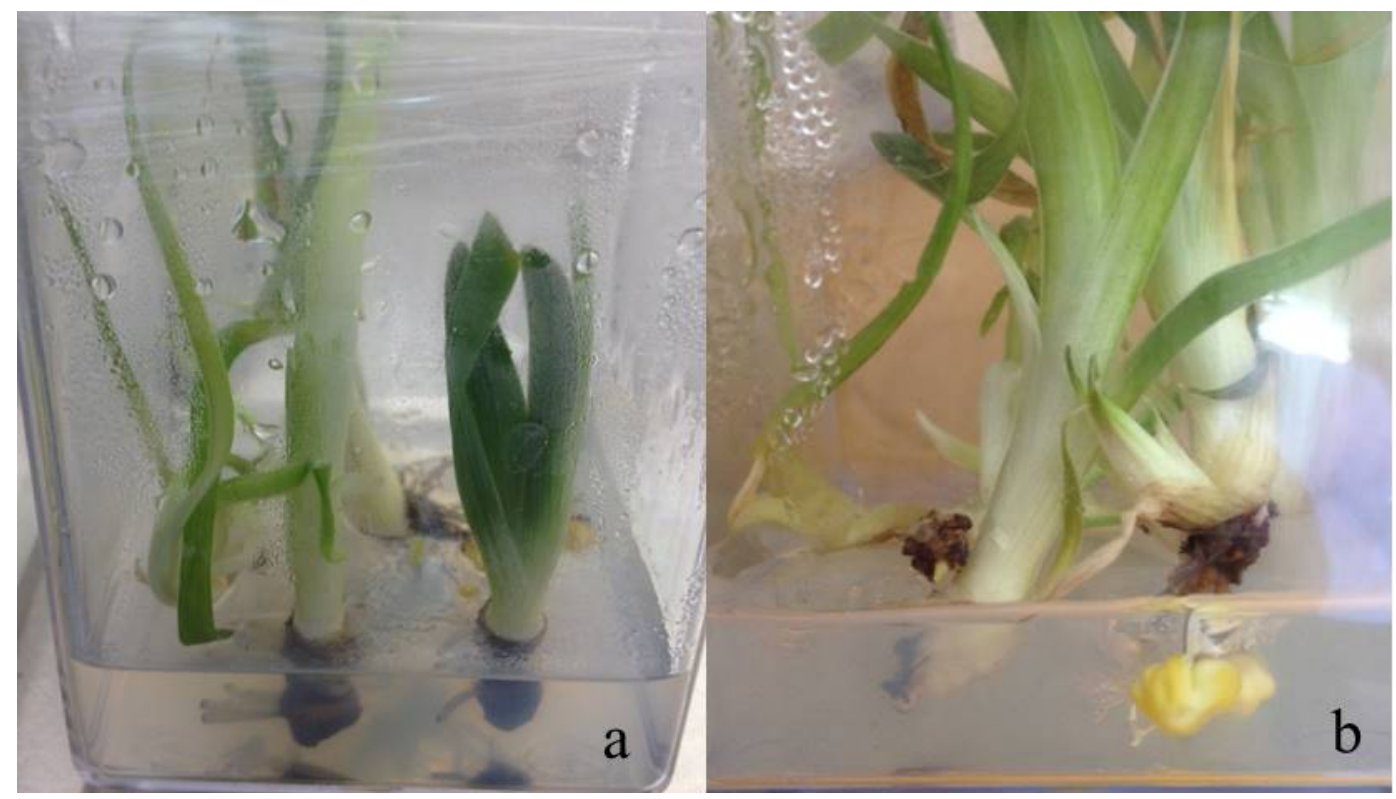

Sekil 6. Iris sari bitkiciklerinin (a) kontrol grubu, (b) 5 no'lu ortamda kök gelișimi.

Figure 6. Iris sari plantlets (a) control group, (b) root development in 5 number medium. 


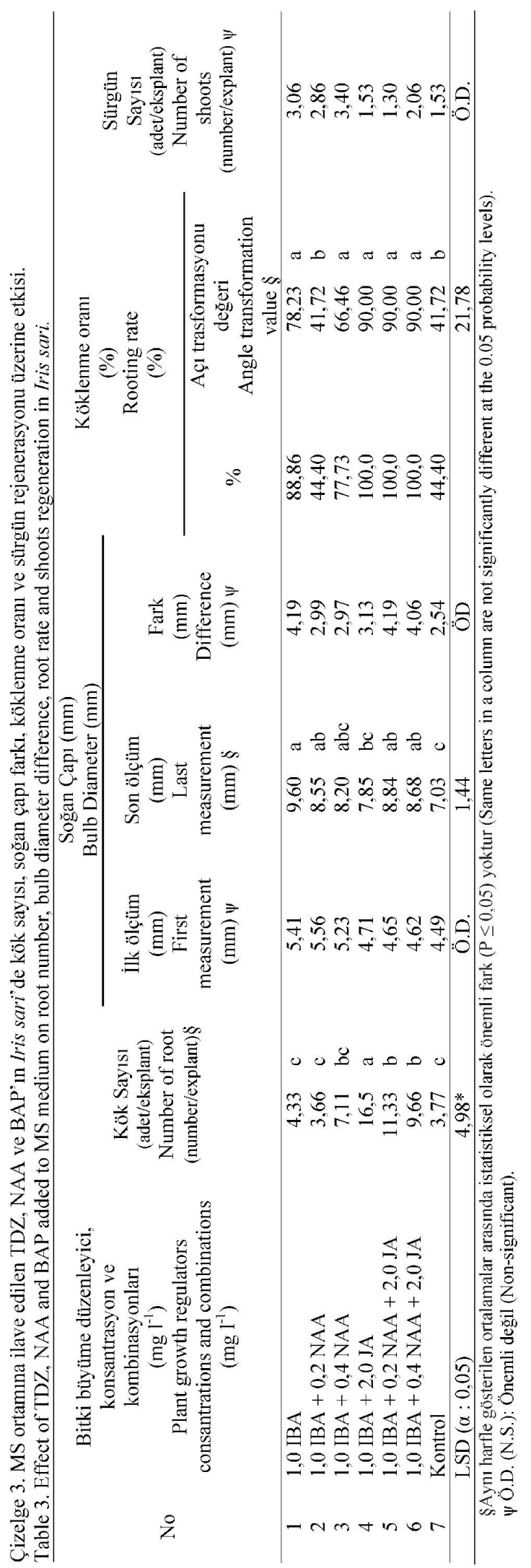




\section{SONUÇ}

Geofitler içerisinde yer alan Iris L. türlerinin çoğaltımı ve yetiştirilmesi oldukça zordur. Iris L. türlerinin de dahil olduğu bazı geofit bitki türlerinde (Sternbergia fischeriana, Ornithogalum platyphyllum, Muscari azureum, Iris sari ve Iris schachtii), alternatif eksplant kaynağ 1 olarak olgunlaşmamış embriyoları, sürgün rejenerasyonu çalışmalarında kullanılmıştır (Mirici ve ark., 2005; İpek ve ark., 2009; Uranbey, 2010; Uzun ve ark., 2014). Eksplant kaynağı olarak kullanılan embriyolar, geofit bitki tohumlarında, kimyasal gerektiren bazı dormansi kırma uygulamalarında ya da uzun süren tohumdan çoğaltım çalışmalarına gerek olmadan, in vitro mikroçoğaltım çalışmalarıyla, daha kolay ve kısa sürede çoğaltımı sağlayabilmektedir (Doğan ve Çağlar, 2018). Çoğaltımı sağlanan bitkilerin dış koşullara adaptasyon süreci de sağlıklı bitkilerin yanı sıra sağlam bir kök yapısını gerektirmektedir.

$\mathrm{Bu}$ çalışmada, Iris sari endemik türüne ait olgunlaşmamış embriyolar başlangıç eksplantı olarak kullanılmış olup, bitkinin sürgün, kök ve bulb gelişimi üzerinde bazı bitki büyüme düzenleyicilerin etkileri araştırılmıştır. Yapılan denemelerde bitkiciklerin köklenme oranları ile birlikte sürgün oluşum oranları da incelenmiştir. $\mathrm{Bu}$ amaçla çalışmamızda farklı bitki büyüme düzenleyicilere ek olarak, bitki büyüme düzenleyici olarak ta bilinen jasmonik asit, kök ve bulb gelişimini desteklemek üzere besin ortamlarına eklenmiştir.

En iyi sürgün oluşturma oranı 1,0 $\mathrm{mg} \mathrm{l}^{-1} \mathrm{BA}+0,5$ mg $1^{-1}$ NAA içeren MS besin ortamında kültüre alınan eksplantlardan elde edilmiştir. Besin ortamı içerisine ilave edilen IBA oksin grubu bitki büyüme düzenleyici olduğundan, köklenme üzerine olan etkisi yüksektir. Sürgünlerin köklenme oranı ve bulb çap1 gelişimleri değerlendirildiğinde, IBA ve IBA ile doğru kombinasyonlarının sağlandığ JA içeren MS besin ortamlarında en iyi sonuçların elde edildiği görülmektedir.

JA ile sitokinin ve oksin kombinasyonlarının kullanıldığ $\breve{1}$ denemede köklenmeyi sadece JA'in değil bunun yanında doğru yapılan sitokinin ve oksin kombinasyonlarının kayda değer ölçüde etkilediği gözlenmiştir. JA ile yapılan oksin kombinasyonlarında, kök sayısı ve köklenme oranındaki artışın nedeni; kullanılan oksinin, JA ile desteklenmesiyle meydana geldiği, ters orantılı olarak ta sürgün rejenerasyonu oranında azalışın olduğu gözlemlenmiştir.

$\mathrm{Bu}$ şekilde yapılacak in vitro çalışmalarda, oksin konsantrasyonlarının arttırılarak JA asit ile birlikte kullanımları ile, JA asitin toprakaltı depo organlarının gelişimi üzerindeki etkisinin önemli şekilde ortaya koyulacağı ve başarı oranını olumlu yönde arttıracağı düşünülmektedir. Bununla birlikte in vitro sürgünlerin alt kültüre alınma sayısı da göz ardı edilmemesi gereken bir etkendir.

Bu çalışmada da görüldüğü gibi, doku kültürü çalışmalarında aynı bitki türlerinden, aynı besin ortamlarında elde edilen farklı sonuçlarla karș1laşılması muhtemeldir. Neden olarak; in vitro bitki rejenerasyonunu etkileyen unsurlar arasında olan bitkinin genotipi, bitki örneğinin toplanma zamanı, bitki yaşı, habitatı, kültüre alma koşulları gibi faktörler gelmektedir.

Elde edilen sonuçlar, geofit bitkiler içerisinde yer alan, aynı zamanda süs bitkisi potansiyeli olan gösterişli çiçeklere sahip Iris L. türleri ile ilgili gerek sürgün oluşumunun teșviği gerek ise bitkinin sürekliliğinin sağlanması için elzem olan kök oluşumunun teşviği ve toprakaltı depo organlarının geliştirilmesi ya da irileştirilmesi amacıyla yapılacak olan in vitro çalışmalar için ümitvar nitelikte görülmektedir.

\section{TEŞEKKÜR}

$\mathrm{Bu}$ çalışma, Kahramanmaraş Sütçü İmam Üniversitesi, Fen Bilimleri Bilimsel Araştırma Projesi tarafindan desteklenen 'Türkiye'nin Bazı Endemik Iris Türlerinde In vitro Rejenerasyon ve In vitro Poliploid Bitki Oluşturma Üzerine Araştırmalar' Doktora Tez Projesinin bir bölümünü oluşturmuştur ve K.S.Ü. Ziraat Fakültesi, Bahçe Bitkileri Bölümü, Biyoteknoloji Laboratuvarında yürütülmüştür. 


\section{LITTERATÜR LİSTESI}

Al-Gabbiesh, A., D. S. Hassawi, and F. U. Afifi. 2006. In vitro propagation of endangered Iris species. Journal of $\begin{array}{llll}\text { Biological Sciences } 6 & \text { (6): } 1035-1040 .\end{array}$ https://doi.org/10.3923/jbs.2006.1035.1040.

Anonymous. 2019. The Plant List. The working list of all plant species. http://www.theplantlist.org/tpl1.1/ search?q= Iris + sari + SCHOTT + ex + BAKER. Erişim: May1s 2015.

Aswath, C., S. M. Deepa, and M. L. Choudhary. 2003. Commercial multiplication of gerbera (Gerbera jamesonii Bolus) through in vitro shoot tip culture. Journal of Ornamental Horticulture 6 (4): 303-309.

Baruch, E., and F. Quak. 1966. Virus free plants of Iris 'Wedgewood' obtained by meristem culture. Neth. J. Plant Pathol. 71: 270-273. https://doi.org/ 10.1007/ BF02650217.

Bhojwani, S. S., and M. K. Razdan. 1996. Plant Tissue Culture: Theory and practice. A Revised Edition. Elsevier Science, Amsterdam. pp.1-767.

Boltenkov, E. V., and E. V. Zarembo. 2005. In vitro regeneration and callogenesis in tissue culture of floral organs of the genus Iris (Iridaceae). Biology Bulletin 32: 174-179. https://doi.org/10.1007/s10525-005-0020-7.

Dagcı, E. K., İzmirli, M. ve M. Dıgrak. 2002. Kahramanmaraş ilinde yetişen bazı ağaç türlerinin antimikrobiyal aktivitelerinin araştırılması. KSU Fen ve Mühendislik Dergisi 5 (1): 38-46.

De Gyves, E. M., C. A. Sparks, A. F. Fieldsend, P. A. Lazzeri, and H. D. Jones. 2001. High frequency of adventitious shoot regeneration from commercial cultivars of evening primrose (Oenothera spp.) using thidiazuron. Annals of Applied Biology 138 (3): 329-332. https://doi.org/10.1111/j.1744-7348.2001.tb00117.x.

Dogan, S., ve G. Caglar. 2018. In vitro shoot proliferation via immature embryos of Iris kirkwoodiae Chaudhary. Anadolu, J. of AARI 28 (2): 48-54.

Erken, K., E. Kaya, N. Özhatay, B. Şener, E. Uysal, N. Arslan, Z. Uçkun, Ş. Ellialtıoglu. C. Hantaş, S. Erkal, A. Atak ve A. Fidanc1. 2009. Türkiye'de Yetişen Iris Türlerinin Taranması Seleksiyonu Yetiştirme Tekniklerinin Belirlenmesi ve Süs Bitkileri Sektörüne Kazandırılması (Tübitak 1007, 105G068 No'lu Proje Sonuç Raporu, Bazı Doğal Bitkilerin Kültüre Alınması, Yeni Tür Çeşitlerin Süs Bitkileri Sektörüne Kazandırılması-I, İş Paketi 3), Atatürk Bahçe Kültürleri Merkez Araştırma Enstitüsü Yayın No: 249. Yalova.

Francescangeli, N. 2009. Paclobutrazol and cytokinin to produce Iris (Iris hollandica Tub) in pots. Chilean Journal of Agricultural Research 69 (4): 509-515.

Gozu, Y., Y. Mineyyuki, N. Masahiro, and N. Ryujino. 1993. In vitro propagation of Iris pallida. Plant Cell Report 13 (1): 12-16. https://doi.org/10.1007/BF00232307.
Güner, A. 2012. Iris L. s.535-540. Güner, A., S. Aslan, M. Vural, and T. Babaç (Eds.). Türkiye Bitkileri Listesi (Damarlı Bitkiler) Nezahat Gökyiğit Botanik Bahçesi ve Flora Araştırmaları Derneği Yayını. İstanbul, 1290s.

Hussey, G. 1976. In vitro release of axillary shoots from apical dominance in monocotyledonous plantlets. Annals of Botany 40 (170): 1323-1325.

Ipek, A., S. Çöçü, S. Uranbey, D. Kaya, B. Gürbüz, N. Aslan,C. Sancak, G. Akdoğan ve S. Ozcan. 2009. In vitro bulblet production from immature embryos of ornamental plant Ornithogalum platyphyllum Boiss. Res. J. Biotechnol. 4 (4): 21-25.

Je'han, H., D. Courtois, C. Ehret, K. Lerch, and V. Pe'tiard. 1994. Plant regeneration of Iris pallida Lam. and Iris germanica https://doi.org/: 10.1007/BF00231621.

Jevremović, S., and L. J. Radojević. 2002. Plant regeneration from suspension cultures of Iris pumila L. Proc. XX Eucarpia Symp. on New Ornamentals II. ISHS Acta Hort. 572, 59-65. https://doi.org/10.17660/ActaHortic. 2002.572.6.

Kancherla, S. L., and P. L. Bhalla. 2003. Plant regeneration of the Australian native ornamental genus, Pandora. The Journal of Horticulture Science and Biotechnology 78 (2): 148-153.

Kim, E. K., E. J. Hahn, H. N. Murthy, and K. Y. Paek. 2003. High frequency of shoot multiplication and bulblet formation of garlic in liquid cultures. Plant Cell Tissue and Organ Culture 73: 231-236. https://doi.org/ 10.1023/A:1023029302462.

Laublin, G., and M. Cappodocia. 1992. In vitro ovary culture of some apogon garden Irises (Iris pseudacorus L., I. setosa Pall., I. versicolor L.) Bot. Acta. 105 (4): 319322.

Mirici, S., I. Parmaksız, S. Ozcan, C. Sancak, S. Uranbey, E. O. Sarıhan, A. Gumuscu, B. Gurbuz, and N. Arslan. 2005. Efficient In vitro bulblet regeneration from 1mmature embryos of endangered Sternbergia fischeriana, Plant Cell, Tissue and Organ Culture 80: 239-246. https://doi.org/10.1007/s11240-004-3016-y.

Murashige, T., and F. Skoog. 1962. A revised medium for rapid growth and bioassay with tobacco tissue cultures. Physiologia Plantarum 15: 473-497.

Nasırcılar, A. G., S. Mirici, Ö. Karagüzel, Ö. Eren, and I. Baktir. 2011. In vitro propagarion of endemic and endangered Muscari mirum from different explant types. Turkish Journal of Botany 35 (1): 37-43. https://doi.org/10.3906/bot-0907-90.

Nasircilar, A. G. ve I. G. Deniz. 2014. An Alternative plant propagation and conservation process for Iris pampyhlica an endemic and endangered geophyte. Fifth International Scientific Agricultural Symposium Agrosym. pp.346-351. 
Nhut, D. T., B. V. Le, N. T. Minh, J. T. de Silva, S. Fukai, M. Tanaka, and K. T. T. Van. 2002. Somatic embryogenesis through pseudobulblet thin cell layer of Lilium longiflorum. Plant Growth Regulation 37 (2): 193-198.

Paek, K. Y., and H. N. Murthy. 2002. High frequency of bulblet regeneration from bulb scale sections of Fritillaria thunbergii. Plant Cell Tiss. Org. Cult. 68 : 247-252. https://doi.org/10.1023/A:1013952803887.

Randolph, L. F. 1945. Embryo culture of Iris seed. Bull. Am. Iris Soc. 98: 33-45.

Santos, I., and R. Salema. 2000. Promotion by Jasmonic Acid of bulb formation in shoot cultures of Narcissus triandrus L. Plant Growth Regulation 30 (2): 133-138.

Selles, M., F. Viladomat, J. Bastida, and C. Codina. 1999. Callus induction, somatic embryogenesis and organogenesis in Narcissus confusus: correlation between the state of differentiation and the content of galanthamine and related alkaloids. Plant Cell Rep. 18: 646-651. https://doi.org/10.1007/s002990050636.

Simonet, M. 1932. Plant regeneration of Iris pallida Lam. and Iris germanica L. via somatic embryogenesis from leaves, apices and young flowers. Bull Biol France et Belgique 105: 255-444.

Steel, R. G. D., and J. H. Torrie. 1980. Principles and Procedures of Statistics. Second Ed. McGraw-Hill Book Company Inc., New York.

Tan, A. 1996. Turkey; Country Report to the FAO International Technical Conference on Plant Genetic Resource. pp.5-45.
Thomas, T. D. 2007. High-frequency, direct bulblet induction from rhizome explants of Curculigo orchioides Gaertn., an endangered medicinal herb. In Vitro Cellular Development Biology - Plant 43 (5): 442-448. https://doi.org/ 10.1007/s11627-007-9091-0.

Uranbey, S. 2010. In vitro bulblet regeneration from immature embryos of Muscari azureum. African Journal of Biotechnology 9 (32): 5121-5125. https://doi.org/ 10.5897/AJB09.1990.

Uzun, S., A. İ. İlbaş, A. İpek, N. Arslan, and S. Barpete. 2014. Efficient in vitro plant regeneration from immature embryos of endemic Iris sari and I. schachtii. Turkish Journal of Agriculture and Forestry 38: 348-353. https://doi.org/10.3906/tar-1306-47.

Uzun, S., A. İ. İlbaş, A. İpek, E. Beyzi, S. Uranbey ve N. Arslan. 2016. Endemik kaba navruz bitkisinin (Iris galatica Siehe) in vitro çoğaltımı. Tarla Bitkileri Merkez Araştırma Enstitüsü Dergisi 25 (1): 35-41.

Wang, Y., Z. Jeknić, R. C. Ernst, and T. H. H. Chen. 1999. Improved plant regeneration from suspension cultured Cells of Iris germanica L. 'skating party'. HortScience 34 (7): 1271-1276.

Y1lmaz-Gökdoğan, E. ve E. Kaya. 2017. Bitki biyoçeşitliliğinin kısa, orta ve uzun süreli korunması: biyoteknoloji ve kriyoprezervasyon. Mustafa Kemal Üniversitesi Ziraat Fakültesi Dergisi 22 (1): 87-111.

Yurtsever, N. 1984. Deneysel İstatistik Metotları. Köy Hizmetleri Toprak ve Gübre Arş. Enst. Müdürlüğü Yayınları Genel Yayın No. 121 Ankara. 